\title{
ECOLOGICAL LIFE ZONES OF BRAZIL
}

\author{
Andressa Tres ${ }^{1 *}$, Alexandre França Tetto ${ }^{2}$, Ronaldo Viana Soares ${ }^{3}$, William Thomaz Wendling ${ }^{4}$, Gisele Henning \\ Santos 5
}

\begin{abstract}
${ }^{1}$ Universidade Federal do Paraná, Programa de Pós-graduação em Engenharia Florestal, Curitiba, Paraná, Brasil - e-mail: tres.andressa@gmail.com (*AUTOR PARA CORRESPONDÊNCIA)

${ }^{2}$ Universidade Federal do Paraná, Departamento de Ciência Florestais, Curitiba, Paraná, Brasil. - e-mail: tetto@ufpr.br ${ }^{3}$ Universidade Federal do Paraná, Departamento de Ciências Florestais, Curitiba, Paraná, Brasil - e-mail: rvsoares@ufpr.br ${ }^{4}$ Universidade Federal do Paraná, Departamento de Ciências Florestais, Curitiba, Paraná, Brasil - e-mail: wendling@ufpr.br

${ }^{5}$ Universidade Federal do Paraná, Engenheira Florestal, Curitiba, Paraná, Brasil - e-mail: giflorisbe@gmail.com
\end{abstract}

Received for publication: 07/02/2019 - Accepted for publication: 17/04/2019

\begin{abstract}
Resumo
Zonas de vida ecológicas do Brasil. Muitos sistemas de classificação foram desenvolvidos para auxiliar na missão de descrever o clima, mas nenhum é capaz de atender a todas as atividades humanas. O sistema desenvolvido por Holdridge em 1947, chamado de "zonas de vida", é considerado o sistema de classificação climática mais ecológico pelo uso da biotemperatura. Diversos países já possuem um mapa das suas zonas de vida e o objetivo deste estudo é classificar cada município brasileiro de acordo com esse sistema. Dados de temperatura, precipitação, altitude e latitude, cedidos por Alvares et al., (2013), foram aplicados na metodologia descrita em Holdridge (2000). O mapa das zonas de vida foi comparado com o mapa de vegetação por meio de matrizes de correlação, que geraram índices de correspondência de 0 a $100 \%$. Os resultados mostraram que o Brasil tem 35 zonas de vida. As mais comuns são floresta úmida tropical e floresta úmida tropical premontana, cobrindo quase $50 \%$ do território. Após as análises de correlação, foi possível identificar que 21 zonas de vida têm mais de $80 \%$ das suas superfícies explicadas por dois tipos de vegetação ou menos. A distribuição das zonas de vida foi consistente com as características de cada região, em termos de vegetação e clima; desta forma, o sistema de classificação de Holdridge pode ser considerado uma opção relevante e específica para tomadas de decisão na agricultura e silvicultura.

Palavras-chave: Holdridge; ecossistemas; clima; vegetação; biotemperatura
\end{abstract}

\begin{abstract}
Many classification systems were developed to help in the mission of describing climate, but none of them is able to meet all areas of human activity. A system developed by Holdridge in 1947, called "life zones", is considered the most ecological climate classification system because of the use of biotemperature. Several countries already have a life zones map and the purpose of this study is to classify each Brazilian municipalities according to this system. Temperature, precipitation, altitude and latitude data, provided by Alvares et al. (2013), were applied according to the methodology described by Holdridge (2000). The ecological life zones map was compared with the vegetation map through correlation matrices, which generated indices ranging from 0 to $100 \%$. The results showed that Brazil has 35 life zones. The most common are tropical moist forest and tropical premontane moist forest, covering almost $50 \%$ of the country's area. After the analysis of correlations, we could see that $21 \mathrm{LZs}$ have more than $80 \%$ of their surfaces covered by two or less types of vegetation. The LZs distribution was consistent to the characteristics of each region, in terms of vegetation and climate; therefore, the Holdridge system can be considered a relevant and specific option for decision making related to agricultural and forestry activities.

Keywords: Holdridge; ecosystems; climate; vegetation; biotemperature
\end{abstract}

\section{INTRODUCTION}

The distribution of vegetation can hardly be justified or understood if we consider them isolated from the climate in which they are influenced, since this is one of the determining factors in the geographic distribution of natural vegetation. Each vegetal species lives between extreme limits of different climatic factors and elements, beyond which its development would not be possible.

Among the resources that plants need in order to grow, water is often the most limiting resource (TAIZ; ZEIGER, 2009). However, in addition to the availability of water, temperature also plays an essential role in vegetation growth, as it controls the rates of metabolic reactions in cells (MOLLO et al., 2011). Thus, among the

FLORESTA, Curitiba, PR, v. 50, n. 3, p. 1575 - 1584, jul/set 2020.

Tres, A. et.al.

ISSN eletrônico 1982-4688

DOI: $10.5380 /$ rf.v50 i3. 64833 
climatic factors that determine the vegetal ecology, temperature and rainfall are probably the most active (MOLLO et al., 2011; ALVARES et al.; 2012). In agriculture and forestry, these factors can be useful to define crop zoning, sowing dates, and the expected yield levels (ALVARES et al.; 2012). These two factors are the most used in several climate classification systems.

Holdridge (2000) proposed a bioclimatic classification system that is based on climatic parameters (biotemperature and precipitation) and non-climatic parameters (latitude and altitude). This climate classification system is called life zones (LZs) and it aims to group similar ecological associations (HOLDRIDGE, 2000). Instead of using air temperature, as other climate classifications, Holdridge (2000) suggests the use of biotemperature to represent the 'heat' factor in the LZs system. Biotemperature is the temperature range in which the effective growth of plants occurs, i.e., 0 to $30^{\circ} \mathrm{C}$. Below this interval, the plant would paralyze its processes, and above it, the photosynthesis would be zero due to high rates of respiration. The use of biotemperature, as well as the information of latitude and altitude, is the reason why some authors consider LZs an ecological system of climate classification.

Many countries already have a national map based on the LZs of Holdridge. Some examples of countries in Latin America include Colombia (HINCAPIÉ; CAICEDO, 2013), Costa Rica, Honduras, Guatemala, Panama, Nicaragua, El Salvador, Belize (KHATUN; IMBACH; ZAMORA, 2013; IRUNGARAY et al., 2016), Mexico (DURÁN et al., 2014), Bolivia (MINISTERIO DE PLANIFICACIÓN DEL DESAROLLO, 2016), Puerto Rico (KHALYANI et al., 2016) and Argentina (DERGUY, 2017).

Even though this classification is better adapted for the tropics, China (LI et al., 2015), Pakistan (NASIR; AFRASIYAB; ATHAR, 2015), Turkey (TATLI; DALFES, 2016) and India (CHAKRABORTY et al., 2013; SINGH; CHATURVEDI, 2017) are also using this system to relate to the ecosystem mapping and to compare with others climate classifications.

Considering that Brazil is a megadiverse country with a variety of agricultural and forestry activities, a map of Brazilian LZs is essential as a way to subsidize public policies and agricultural and forestry planning and as a tool for territorial management of natural resources. Life zones, as previously mentioned, include geographic (latitude and altitude), climatic (precipitation and temperature) and ecological (biotemperature) data. This wealth of information should be considered as a detailed alternative to, in some cases, replace the use of biomes, which, although necessary in a country of continental proportions, end up generalizing some important peculiarities of ecosystems.

Therefore, the objective of our study was to classify the Brazilian municipalities according to the Holdridge's life zone system and to compare it to the Brazilian vegetation map.

\section{MATERIALS AND METHODS}

\section{Study site}

Brazil is located in central-eastern South America, between the latitudes $5^{\circ} 16^{\prime} 20 " \mathrm{~N} ; 33^{\circ} 45^{\prime} 04^{\prime \prime} \mathrm{S}$ and the longitudes $34^{\circ} 47^{\prime} 35^{\prime \prime} ; 73^{\circ} 59^{\prime} 27^{\prime \prime} \mathrm{W}$, and has a total area of 8.515.759,09 $\mathrm{km}^{2}$ (Brazilian Institute of Geography and Statistics - IBGE, 2011). Altitudes in Brazil vary from $2.93 \mathrm{~m}$ to $1,601.42 \mathrm{~m}$ at sea level (Figure 1A); annual precipitation ranges from $421.28 \mathrm{~mm}$ to $3,619.62 \mathrm{~mm}$ (Figure 1B). The mean annual temperature is $22.22{ }^{\circ} \mathrm{C}$, ranging from 13.08 to $28.0^{\circ} \mathrm{C}$ (Figure 1C). 


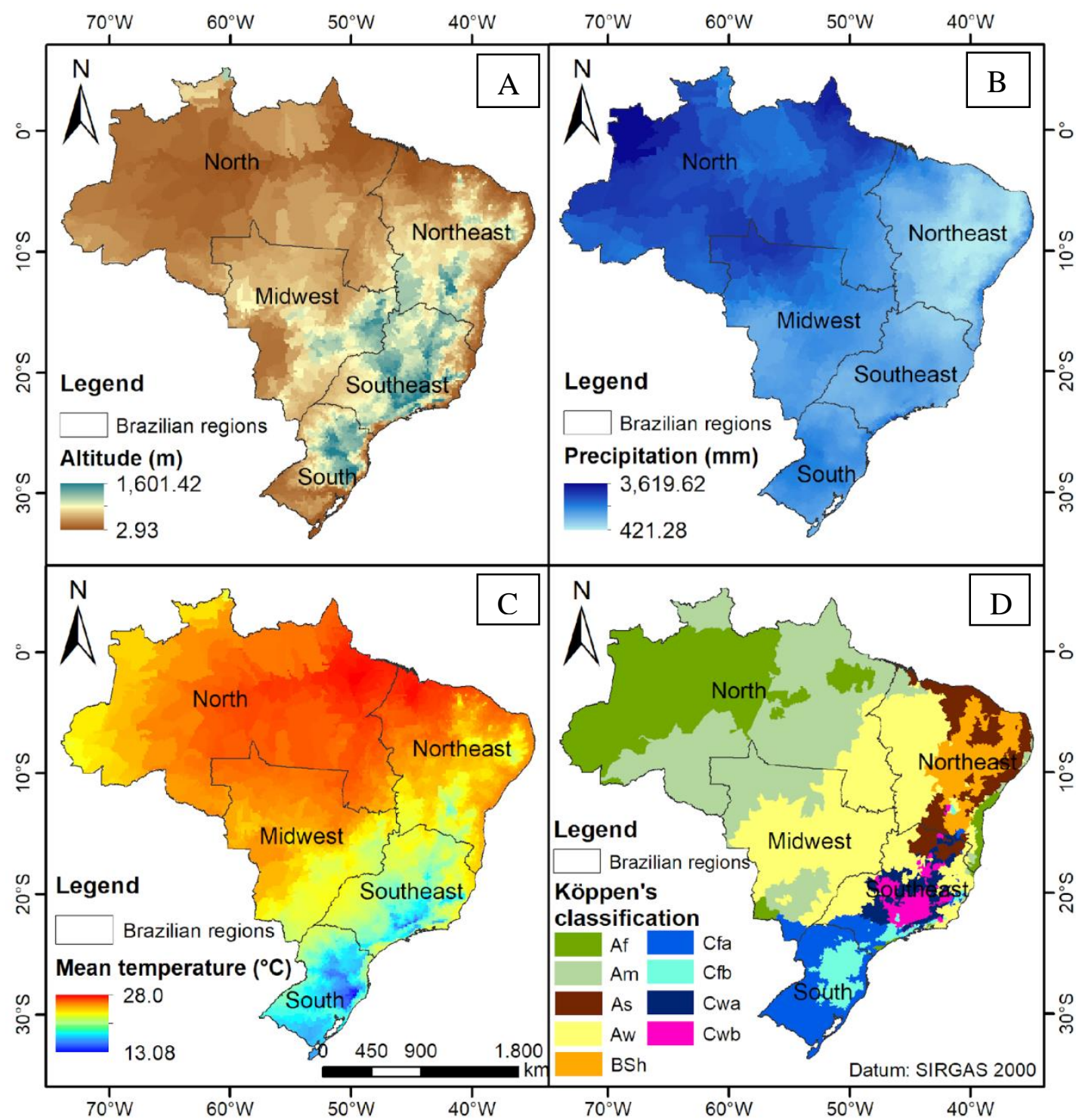

Figure 1. Characterization of the study site. Source: created by the authors based on Alvares et al. (2013). Figura 1. Caracterização da área de estudo. Fonte: elaborado pelos autores baseado em Alvares et al. (2013).

Figure 1D presents nine Brazilian Köppen climatic types, according to Alvares et al. (2013). The surface representativeness of each climate is within parentheses. Four of them are tropical climates: Am (28.2\%) is a monsoon tropical climate; Aw $(26.4 \%)$ is a tropical climate with dry winter; Af $(21.0 \%)$ is a tropical climate without dry season; and As (5.5\%) is a tropical climate with dry summer. Cfa and Cfb are subtropical climates without a defined dry season: $\mathrm{Cfa}(6.8 \%)$ is a humid subtropical climate with hot summer; and Cfb $(2.7 \%)$ is a humid subtropical climate with temperate summer. Brazil also presents other two subtropical climates, but these, in turn, have a defined dry season: Cwa $(2.6 \%)$ is a humid subtropical climate with dry winter and hot summer; and $\mathrm{Cwb}(1.8 \%)$ is a humid subtropical climate with dry winter and temperate summer (1.8\%). Present only in the northeast region, BSh $(5.0 \%)$ is a dry semi-arid climate.

\section{Holdridge's life zones system}

Holdridge proposed a bioclimatic classification system called life zones (LZs) that aims to group similar ecological associations (HOLDRIDGE, 2000). The author believes that the species of plants, which have adapted to a certain ecological niche, are similar from the point of view of physiognomy, even if they are not taxonomically related.

FLORESTA, Curitiba, PR, v. 50, n. 3, p. 1575 - 1584, jul/set 2020

Tres, A. et.al.

ISSN eletrônico 1982-4688

DOI: $10.5380 /$ rf.v50 i3. 64833 
This methodology needs as input data the mean monthly temperature, annual precipitation, latitude and altitude values. Having this data, we can calculate the mean annual biotemperature and the corrected mean annual biotemperature, which will be used to determine the life zone, the latitudinal region and the altitudinal level.

\section{Data obtention}

Climatic data used in this study were provided by Alvares et al. (2013). They are composed of at least 25 years of records, between the years 1950 and 1990, based on 2,950 weather stations for rainfall data and 2,400 for temperature data. This data was obtained from the following sources: Brazilian National Institute of Meteorology (INMET), Brazilian National Department of Works Against Droughts (DNOCS) and Food and Agriculture Organization of the United Nations (FAO/UN).

The database presented the mean monthly temperature, monthly precipitation, mean altitude and Köppen's climate classification for each one of the 5,564 Brazilian municipalities.

Altitude data used by Alvares et al. (2013) were obtained from a Digital Elevation Model (DEM) provided by the Shuttle Radar Topography Mission (SRTM), with a spatial resolution of $90 \mathrm{~m}$. Then, we calculated an average altitude for each municipality.

\section{Data processing and analysis}

A program developed in the FoxPro software (Figure 4) performed the calculations of mean annual biotemperature (Tbio), relation of potential evapotranspiration (Retp) annual rainfall and the classification according to Holdridge's life zone system for the 5,564 Brazilian municipalities. After having the classification, we elaborated a map in the ArcGIS 10.0 program to see the LZs distribution in the country. The surface of each municipality was represented in the map with its respective life zone. Life zones map was superimposed on a vegetation map using the zonal histogram tool. The results were expressed as a percentage of the total LZ area.

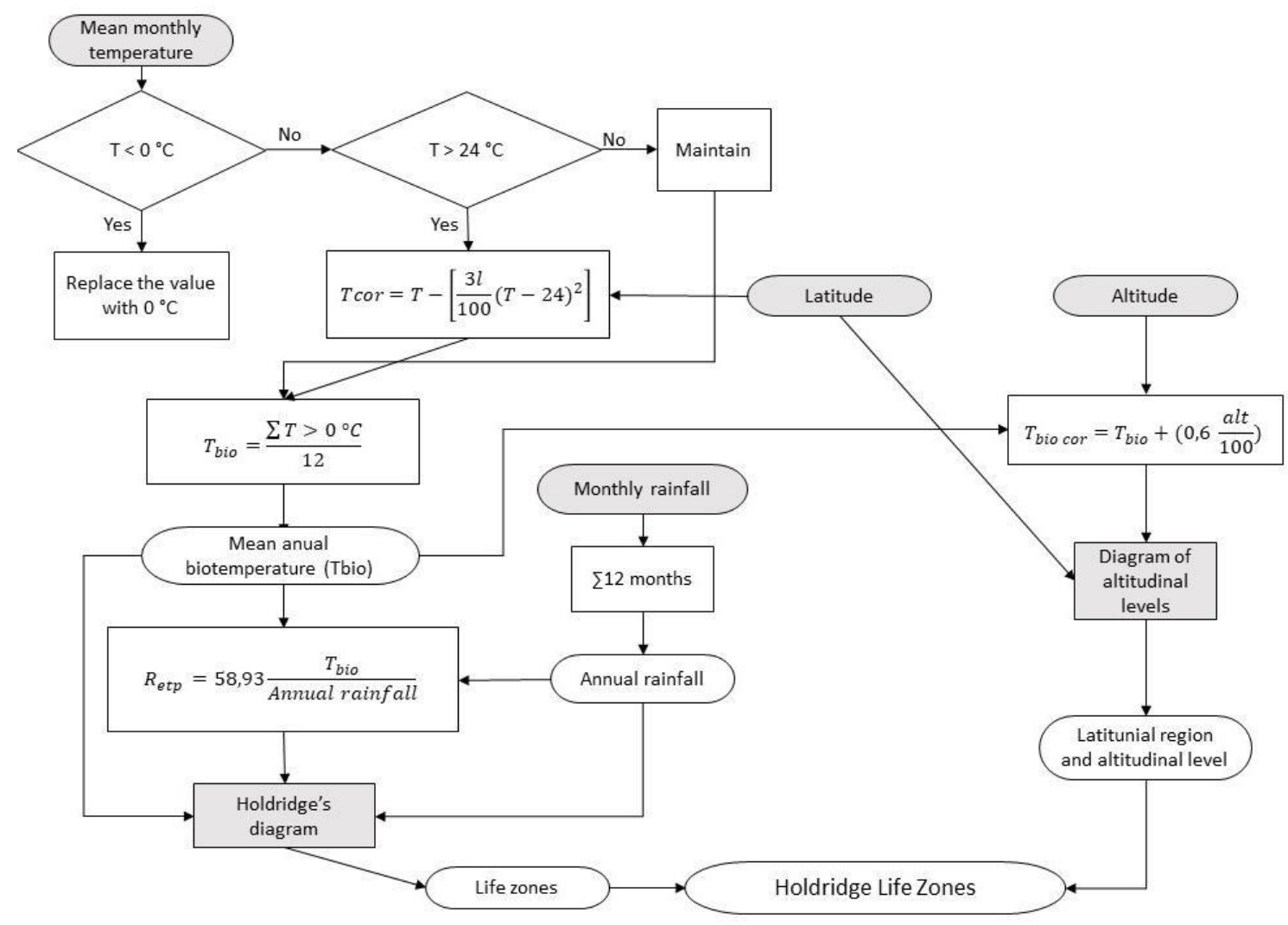

Figure 2. Flowchart of processes performed by the Foxpro software. Figura 2. Fluxograma dos processos realizados no software Foxpro. 


\section{RESULTS}

Figure 3 presents the spatial distribution of Brazilian annual biotemperatures, altitudinal levels, relation of potential evapotranspiration and latitudinal regions.

The mean annual biotemperature was $21.86^{\circ} \mathrm{C}$, varying from $13.08^{\circ} \mathrm{C}$ to $27.69^{\circ} \mathrm{C}$. There was a difference of $0.36^{\circ} \mathrm{C}$ between the mean annual temperature and the biotemperature. Biotemperatures were within three altitudinal levels: lower montane, premontane and basal.

The lower montane altitudinal level was distributed in two regions: southeast and south. In the southeast region, the altitudinal level is presented in the area corresponding to the "Serra da Mantiqueira", whereas in the south region, it is established at the second plateau of Paraná and Santa Catarina states and in the area known as central depression in the state of Rio Grande do Sul.

Clearly, Retp (relation of potential evapotranspiration) had higher values in the northeast region owing to elevated temperatures and low precipitation rates.

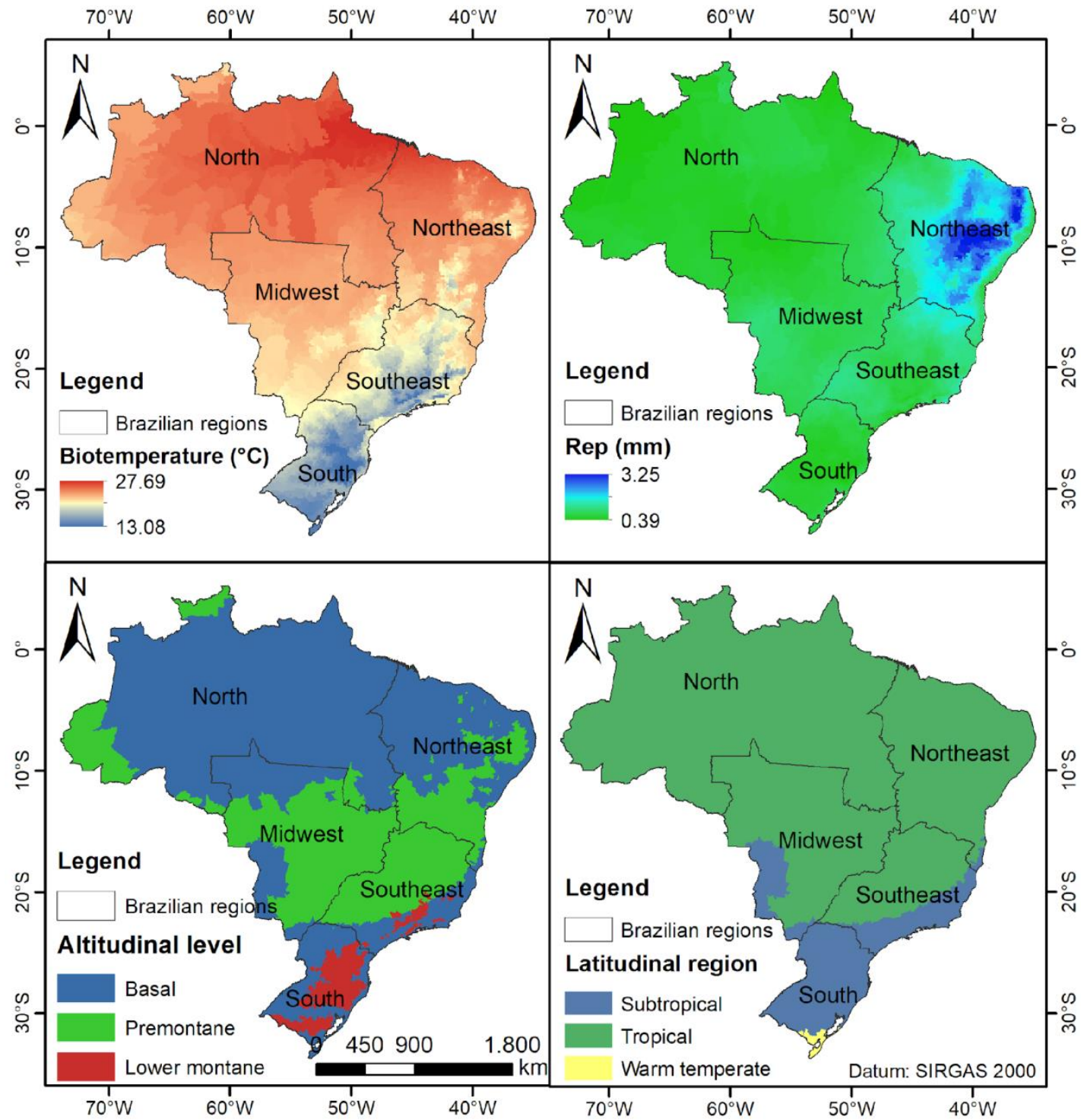

Figure 3. Distribution of biotemperature $\left({ }^{\circ} \mathrm{C}\right)$, relation of evapotranspiration $(\mathrm{mm})$, altitudinal level, and latitudinal region according to Holdridge life zones classification.

Figura 3. Distribuição da biotemperature $\left({ }^{\circ} \mathrm{C}\right)$, relação de evapotranspiração $(\mathrm{mm})$, piso altitudinal e região latitudinal de acordo com a classificação das zonas de vida de Holdridge. 
We found 35 LZs in Brazil (Table 1), most of them (60.23\%) classified as moist forest. The largest Brazilian LZ was a tropical moist forest and together with the second largest LZ, they cover almost $50 \%$ of the country's area.

Table 1. Representativeness of Holdridge life zones by area $\left(\mathrm{km}^{2}\right)$ and percentage $(\%)$ in Brazil.

Tabela 1. Representatividade das zonas de vida de Holdridge por área $\left(\mathrm{km}^{2}\right)$ e porcentagem (\%) no Brasil.

\begin{tabular}{|c|c|c|}
\hline Holdridge life zones & Area $\left(\mathbf{k m}^{2}\right)$ & $\%$ \\
\hline Tropical moist forest & $2,857,146.01$ & 33.55 \\
\hline Tropical premontane moist forest & $1,324,414.95$ & 15.55 \\
\hline Subtropical moist forest & $648,947.75$ & 7.62 \\
\hline Tropical moist/wet forest & $496,070.64$ & 5.83 \\
\hline Tropical dry forest & $378,232.87$ & 4.44 \\
\hline Tropical premontane moist/wet forest & $371,392.95$ & 4.36 \\
\hline Tropical premontane dry forest & $310,674.14$ & 3.65 \\
\hline Tropical dry/moist forest & $268,434.95$ & 3.15 \\
\hline Subtropical lower montane moist forest & $260,635.11$ & 3.06 \\
\hline Tropical very dry/dry forest & $184,076.56$ & 2.16 \\
\hline Tropical premontane moist/dry forest & $178,196.60$ & 2.09 \\
\hline Tropical very dry forest & $177,836.64$ & 2.09 \\
\hline Tropical premontane wet/moist forest & $158,996.95$ & 1.87 \\
\hline Tropical moist/dry forest & $151,917.14$ & 1.78 \\
\hline Tropical premontane dry/moist forest & $130,197.53$ & 1.53 \\
\hline Tropical wet/moist forest & $108,597.96$ & 1.28 \\
\hline Tropical premontane wet forest & $75,838.54$ & 0.89 \\
\hline Tropical dry/very dry forest & $63,718.83$ & 0.75 \\
\hline Subtropical wet/moist forest & $57,958.94$ & 0.68 \\
\hline Tropical premontane dry/very dry forest/thorn woodland & $55,318.95$ & 0.65 \\
\hline Tropical premontane thorn woodland/dry/very dry forest & $41,399.19$ & 0.49 \\
\hline Subtropical moist/dry forest & $38,519.25$ & 0.45 \\
\hline Subtropical lower montane moist/wet forest & $29,759.43$ & 0.35 \\
\hline Warm temperate moist forest & $28,319.50$ & 0.33 \\
\hline Tropical premontane thorn woodland & $25,439.54$ & 0.30 \\
\hline Tropical premontane very dry forest/thorn woodland/dry forest & $24,599.56$ & 0.29 \\
\hline Tropical very dry forest/thorn woodland & $17,639.63$ & 0.21 \\
\hline Subtropical dry/moist forest & $14,519.71$ & 0.17 \\
\hline Subtropical lower montane wet/moist forest & $9,959.76$ & 0.12 \\
\hline Tropical lower montane moist forest & $9,839.77$ & 0.12 \\
\hline Subtropical lower montane wet forest & $7,679.85$ & 0.09 \\
\hline Subtropical moist/wet forest & $4,319.95$ & 0.05 \\
\hline Subtropical wet forest & $2,879.94$ & 0.03 \\
\hline Tropical thorn woodland/very dry forest & $1,560.00$ & 0.02 \\
\hline Subtropical dry forest & 720.01 & 0.01 \\
\hline Total & $8,515,759.09$ & 100.00 \\
\hline
\end{tabular}

Only the two smallest life zones presented complete correspondence with just one type of vegetation (Table 2) but we can say that 19 LZs have more than $80 \%$ of their surfaces covered by two types of vegetation. This includes the two biggest Brazilian LZs: tropical moist forest and tropical premontane moist forest. The first one was best correlated with Ombrophilous forests and the second one with savanna.

FLORESTA, Curitiba, PR, v. 50, n. 3, p. 1575 - 1584, jul/set 2020

Tres, A. et.al.

ISSN eletrônico 1982-4688

DOI: $10.5380 /$ rf.v50 i3. 64833 
Table 2. Percentage of correspondence between Holdridge life zones and Brazilian vegetation.

Tabela 2. Porcentagem de correspondência entre as zonas de vida de Holdridge e a vegetação brasileira.

\begin{tabular}{|c|c|c|c|c|c|}
\hline Holdridge life zones & Index 1 & Vegetation & Index 2 & Vegetation & Index 1+2 \\
\hline Subtropical dry forest & 100.0 & ODF & - & - & 100.0 \\
\hline Tropical thorn woodland/very dry forest & 100.0 & N-SAV & - & - & 100.0 \\
\hline Tropical very dry forest/thorn woodland & 98.2 & N-SAV & 1.8 & $\mathrm{SAV} / \mathrm{N}-\mathrm{SAV} / \mathrm{SF}$ & 100.0 \\
\hline Tropical premontane wet forest & 94.6 & OOF & 5.4 & ODF & 100.0 \\
\hline Trop. premont. very dry forest/thorn woodland/dry forest & 91.2 & N-SAV & 5.0 & N-SAV/SF & 96.2 \\
\hline Tropical very dry forest & 91.1 & N-SAV & 6.3 & $\mathrm{~N}-\mathrm{SAV} / \mathrm{SF}$ & 97.4 \\
\hline Subtropical wet forest & 85.7 & ODF & 14.3 & MOF & 100.0 \\
\hline Subtropical moist/wet forest & 75.0 & ODF & 25.0 & ODF/MOF & 100.0 \\
\hline Tropical premontane thorn woodland & 74.4 & N-SAV & 11.6 & $\mathrm{SAV} / \mathrm{SF}$ & 86.0 \\
\hline Tropical premontane dry/very dry forest/thorn woodland & 73.3 & N-SAV & 16.1 & N-SAV/SF & 89.4 \\
\hline Tropical premontane thorn woodland/dry/very dry forest & 72.3 & N-SAV & 11.5 & SAV/SF & 83.8 \\
\hline Tropical very dry/dry forest & 70.7 & N-SAV & 9.8 & N-SAV/SF & 80.5 \\
\hline Subtropical moist/dry forest & 61.8 & ODF & 35.0 & SSF & 96.8 \\
\hline Subtropical lower montane moist/wet forest & 61.7 & Steppe & 31.9 & MOF & 93.6 \\
\hline Tropical premontane moist forest & 60.8 & SAV & 20.8 & SAV/SF & 81.6 \\
\hline Tropical moist forest & 59.9 & ODF & 20.5 & OOF & 80.4 \\
\hline Subtropical lower montane wet forest & 59.1 & MOF & 40.9 & Steppe & 100.0 \\
\hline Tropical lower montane moist forest & 55.6 & SSF & 25.0 & SF/MOF & 80.6 \\
\hline Tropical wet/moist forest & 55.3 & Campi./OF & 33.4 & Campinarana & 88.7 \\
\hline Warm temperate moist forest & 55.2 & $\mathrm{PF}$ & 40.2 & Steppe & 95.4 \\
\hline Tropical dry/moist forest & 53.3 & SAV & 11.8 & SAV/SF & 65.1 \\
\hline Subtropical lower montane wet/moist forest & 53.1 & Steppe & 40.6 & $\mathrm{MOF}$ & 93.7 \\
\hline Tropical premontane wet/moist forest & 50.3 & OOF & 25.7 & ODF & 76.0 \\
\hline Tropical dry forest & 47.7 & SAV & 10.9 & N-SAV/SF & 58.6 \\
\hline Tropical moist/wet forest & 47.3 & ODF & 22.0 & OOF & 69.3 \\
\hline Tropical premontane dry/moist forest & 44.5 & SAV & 28.9 & SSF & 73.4 \\
\hline Subtropical wet/moist forest & 42.0 & SDF & 27.1 & Steppe & 69.1 \\
\hline Subtropical dry/moist forest & 40.5 & SSF & 31.0 & ODF & 71.5 \\
\hline Tropical premontane moist/dry forest & 38.9 & SSF & 34.4 & SAV & 73.3 \\
\hline Subtropical lower montane moist forest & 38.8 & MOF & 32.4 & Steppe & 71.2 \\
\hline Tropical moist/dry forest & 33.8 & SAV & 32.2 & ODF & 66.0 \\
\hline Tropical dry/very dry forest & 32.3 & N-SAV & 19.6 & $\mathrm{~N}-\mathrm{SAV} / \mathrm{SF}$ & 51.9 \\
\hline Tropical premontane dry forest & 27.5 & SDF & 22.0 & N-SAV/SF & 49.5 \\
\hline Subtropical moist forest & 27.4 & SSF & 21.6 & SAV & 49.0 \\
\hline Tropical premontane moist/wet forest & 26.7 & SAV & 25.3 & OOF & 52.0 \\
\hline
\end{tabular}

Note: Campi. - Campinarana; MOF - Mixed Ombrophilous Forest; N-SAV - northeast-savanna; ODF - Ombrophilous Dense Forest; OF Ombrophilous Forest; OOF - Ombrophilous Open Forest; PF - pioneer forest; SAV - Savanna; SDF - Seasonal Deciduous Forest; SF Seasonal Forest; SSF - Seasonal Semideciduous Forest.

Regarding LZs distribution (Figure 5), the most humid LZ found was the wet forest, located mainly in the state of Amazonas, and the driest LZ was the thorn woodland, located in the central area of the northeast region.

FLORESTA, Curitiba, PR, v. 50, n. 3, p. 1575 - 1584, jul/set 2020.

Tres, A. et.al.

ISSN eletrônico 1982-4688

DOI: 10.5380/rf.v50 i3. 64833 


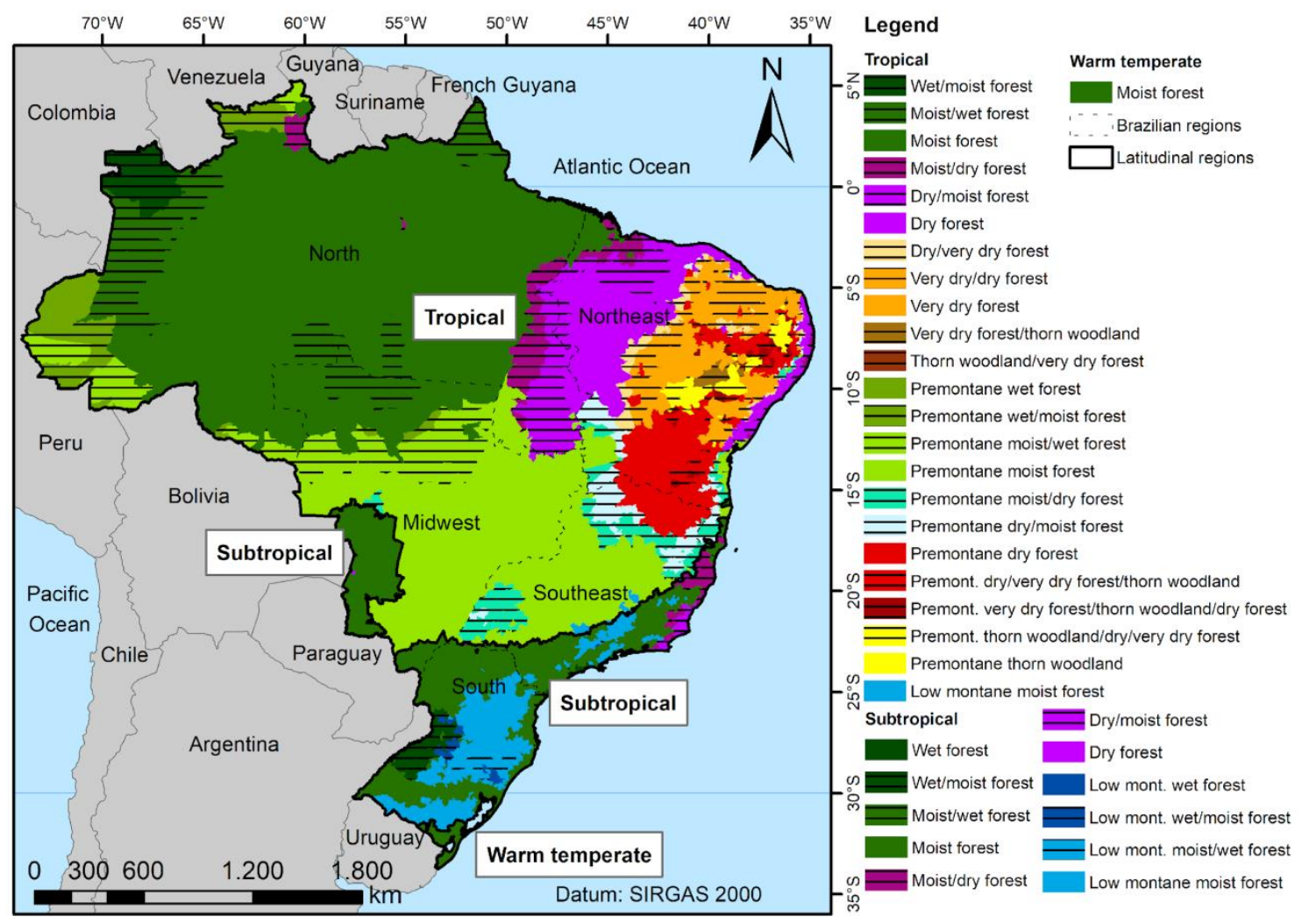

Figure 5. Holdridge life zones distribution in Brazil.

Figura 5. Distribuição das zonas de vida de Holdridge no Brasil.

Of the nine LZs found in the Brazilian midwest region, the tropical premontane moist forest was the most expressive, covering $50.86 \%$ of the midwest region area and practically the entire state of Goiás. Transition zones with wet forests were concentrated in the northern portion of this region, where the Amazon biome occurs.

Northeast was the most heterogeneous region of Brazil, where $21 \mathrm{LZs}$ were identified. In general, the most humid life zones were located in the northern area of Maranhão state and the south coast of Bahia state. The tropical dry forest was the most common life zone in that region $(23.29 \%)$, whereas the thorn woodland, the driest life zone in Brazil, only occurred in the northeast of Brazil.

The northern region presented $10 \mathrm{LZs}$, and the tropical moist forest was the predominant type, with $67.81 \%$ of the total area. In the western portion of this region, the transition zones tended to be wet forests, such as tropical moist/wet forest and tropical wet/moist forest; in the eastern portion, the driest transition zones predominated in the border of the northeast region.

Premontane tropical moist forest is the most common life zone in southeast Brazil, covering $40.79 \%$ of the region's area. This life zone changes its latitudinal region and altitudinal level according to the area's proximity to the ocean, which creates the subtropical moist forest, representing $18.10 \%$ of the region. All four life zones with a lower montane altitudinal level are concentrated in the area corresponding to the "Serra da Mantiqueira", where altitudes are more elevated.

In the southern region, subtropical moist forest was the most abundant $(42.77 \%)$. Subtropical lower montane moist forest $(35.71 \%)$, the second largest life zones in the southern region, was found in the second plateau of Paraná state and in the central part of Santa Catarina and Rio Grande do Sul states.

\section{DISCUSSION}

The results of our study show, for the first time, a detailed map of Holdridge life zones in Brazil.

Moist forest, the LZ found in most of the Brazilian territory, is present in all geographic regions, but mainly in the north, center-west, southeast and south areas. In the northeast region, moist forest was found only in northern state of Maranhão and in the west and south coast of Bahia state, due to the higher humidity in those areas, compared to the center of the region.

As expected, the driest LZs were found in the northeast region. It was interesting to see how transitions were established in this area. They gradually became drier up to the central portion.

FLORESTA, Curitiba, PR, v. 50, n. 3, p. 1575 - 1584, jul/set 2020.

Tres, A. et.al.

ISSN eletrônico 1982-4688

DOI: $10.5380 /$ rf.v50 i3. 64833 
Vergara et al. (2013), in a study about how Holdridge LZs could change in a scenario with double $\mathrm{CO}_{2}$ in Latin America, obtained similar results in Brazil although not as detailed. According to them, the moist forest was also the most recurrent LZ in Brazil and the northeast region was classified as dry forest.

In Colombia, as in Brazil, tropical moist forest was the most abundant LZ (HINCAPIÉ; CAICEDO, 2013). In the northern and eastern Bolivia, LZs are similar to those found in Brazil: moist forest, wet forest, rain forest and dry forest. However, the other areas in Bolivia are covered by desert, steppe, thorn steppe, desert shrub, thorn woodland, nival, moist tundra, wet tundra, rain tundra and dry tundra (MINISTERIO DE PLANIFICACIÓN DEL DESAROLLO, 2016).

The analysis of correlation between vegetation and ecological life zones is important as a way to validate the classification according to the characteristics of the study area. Isaac and Bourque (2001), studying the life zones of Saint Lucia, and Szelepcsényi, Breuer and Sümegi (2014), in the Carpathian Region, also approached this relation.

Some limitations of our study are: life zones were calculated for each municipality, where mean values of altitude, temperature and precipitation were considered, which may have disregarded some particularities of each location; some municipalities are much larger than others, i.e., in the northern area, the municipalities are larger than in the southern region. In this case, as we considered mean values, bigger municipalities can be treated as less precise than the smallest ones.

It is important to say that this map responds as a first approximation of Brazilian LZs and came to fulfill the lack of this information for the country. Future research may expand upon these results considering details and particularities of each region.

\section{CONCLUSIONS}

It was possible to conclude that:

- This first approach found 35 LZs for the Brazilian territory. However, considering the size of the country, futures studies are encouraged in local scales.

- The LZs distribution was consistent with the characteristics of each region, in terms of vegetation and climate; therefore, the Holdridge system can be considered a relevant and specific option for decision making related to agricultural and forestry activities.

\section{ACKNOWLEDGMENT}

This study was financed in part by the Coordination of Improvement of Higher Education Personnel Brazil (CAPES) - Finance Code 001. The author would like to thank the Academic Publishing Advisory Center (Centro de Assessoria de Publicação Acadêmica, CAPA - <www.capa.ufpr.br>) of the Federal University of Paraná (UFPR) for assistance with English language editing.

\section{REFERENCES}

ALVARES, C. A.; STAPE, J. L.; SENTELHAS, P. C.; GONÇALVES, J. L. M. Modeling monthly mean air temperature for Brazil. Theor Appl Climatol, v. 113, p. 407 - 427, 2012.

Alvares, C. A.; STAPE, J. L.; SENTELHAS, P. C.; GONÇALVES, J. L. M.; SPAROVEK, G. Köppen's climate classification map for Brazil. Meteorologische Zeitschrift, v. 22, p. 711 - 728, 2013.

CHAKRABORTY, A.; JOSHI, P. K.; GHOSH, A.; AREENDRAN, G. Assessing biome boundary shifts under climate change scenarios in India. Ecological Indicators, v. 34, p. 536 - 547, 2013.

DERGUY, M. R. Classificación ecológica para la República Argentina a partir del modelo de zonas de vida de Holdridge: mapeo, caracterización y tendencias de cambio. Cartografías del Sur, v. 6, p. 140 - 151, 2017.

DURÁN, A. A. C.; LÓPEZ, H. E. F.; MORA, C.; CORRAL, J. A. R.; OJEDA, G. R.; CAMACHO, E. R. Sensitivity of bioclimatic zones of Mexico facing climate change. Revista Mexicana de Ciencias Agrícolas, v. 10, p. $2021-2033,2014$

HINCAPIÉ, J. C. A.; CAICEDO, J. D. P. El cambio climático y la distribución espacial de las formaciones vegetales en Colombia. Colombia Florestal, v. 16, n. 2, p. 171 - 185, 2013.

HOLDRIDGE, L. R. Ecologia basada em zonas de vida. San José, Costa Rica: Instituto Interamericano de Cooperación para la Agricultura, 2000, 216 p.

IBGE. Anuário estatístico do Brasil. Rio de Janeiro: IBGE, 2011, 474 p.

FLORESTA, Curitiba, PR, v. 50, n. 3, p. 1575 - 1584, jul/set 2020

Tres, A. et.al.

ISSN eletrônico 1982-4688 
IRUNGARAY, G. E. P.; CABRERA, G. A. G.; MONZÓN, J. C. R.; IBARRA, R. E. M.; RUANO, J. J. G. Ecosistemas de Guatemala, uma aproximación basada en el sistema de clasificación de Holdridge. Revista Eutopía, n. 1, p. $25-78,2016$.

ISAAC, C.; BOURQUE, C. P. A. Ecological life zones of Saint Lucia. Global Ecology \& Biogeography, v. 10, p. $549-566,2001$.

KHALYANI, A. H.; GOULD, W. A.; HARMSEN, E.; TERANDO, A.; QUINONES, M.; COLLAZO, J. A. Climate change implications for tropical islands: interpolating and interpreting statistically downscaled GCM projections for management and planning. Journal of Applied Meteorology and Climatology, v. 55, p. 265 $282,2016$.

KHATUN, K.; IMBACH, P.; ZAMORA, J. C. An assessment of climate change impacts on the tropical forests of Central America using the Holdridge Life Zone (HLZ) land classification system. IForest, v. 6, p. 183 - 189 , 2013.

LI, G.; WEN, Z.; GUO, K.; DU, S. Simulating the effect of climate change on vegetation zone distribution on the Loess Plateau, Northwest China. Forests, v. 6, p. 2092 - 2108, 2015.

MINISTERIO DE PLANIFICACIÓN DEL DESAROLLO. Lineamientos metodológicos para la formulación de planes territoriales de desarrollo integral. La Paz: Estado Plurinacional de Bolivia, 2016, 118 p.

MOLLO, L.; MARTINS, M. C. M.; OLIVEIRA, V. F.; NIEVOLA, C. C.; FIGUEIREDO-RIBEIRO, R. C. L. Effects of low temperature on growth and non-structural carbohydrates of the imperial bromeliad Alcantarea imperialis cultured in vitro. Plant Cell Tiss Organ Cult, v. 107, p. 141 - 149, 2011.

NASIR, S. M.; AFRASIYAB, M.; ATHAR, M. Application of Holdridge life zones (HLZ) in Pakistan. Pak. J. Bot., v. 47, p. 359 - 366, 2015.

SINGH, J. S.; CHATURVEDI, R. K. Diversity of ecosystem types in India: a review. Proc Indian Natn Sci Acad, v. 83, n. 3, p. $569-594,2017$.

SZELEPCSÉNYI, Z.; BREUER, H.; SÜMEGI, P. The climate of Carpathian Region in the 20th century based on the original and modified Holdridge life zone system. Cent. Eur. J. Geosci. v. 6, p. 293 - 307, 2014.

VERGARA, V.; RIOS, A. R.; GALINDO, L. M.; GUTMAN, P.; ISBELL, P.; SUDING, P. H.; SAMANIEGO, J. The climate and developement challenge for Latin America and the Caribbean: options for climate-resilient, low-carbon development, 2013, 105 p.

TAIZ, L.; ZEIGER, E. Fisiologia vegetal, Porto Alegre: Artmed, 4 ed., 2009, 848 p.

TATLI, H.; DALFES, N. Defining Holdridge's life zones over Turkey. Int. J. Climatol. v. 36, p. 3864 - 3872 , 2016. 